\title{
Does civil servant teachers' job satisfaction influence their absenteeism?
}

\author{
Purwani Puji Utami ${ }^{1}$, Alexius Dwi Widiatna ${ }^{2}$, Herlyna $^{3}$, Alpha Ariani ${ }^{4}$, Faridah Karyati ${ }^{5}$, Ardya Setya \\ Nurvrita ${ }^{6}$ \\ ${ }^{1}$ Civics Education Study Program, STKIP Kusuma Negara, Indonesia \\ ${ }^{2,6}$ Theology Education Study Program, STKIP Widya Yuwana, Indonesia \\ ${ }^{3}$ English Literature Study Program, STBA Pertiwi, Indonesia \\ ${ }^{4,5}$ Educational Administration Study Program, Universitas Achmad Yani Banjarmasin, Indonesia
}

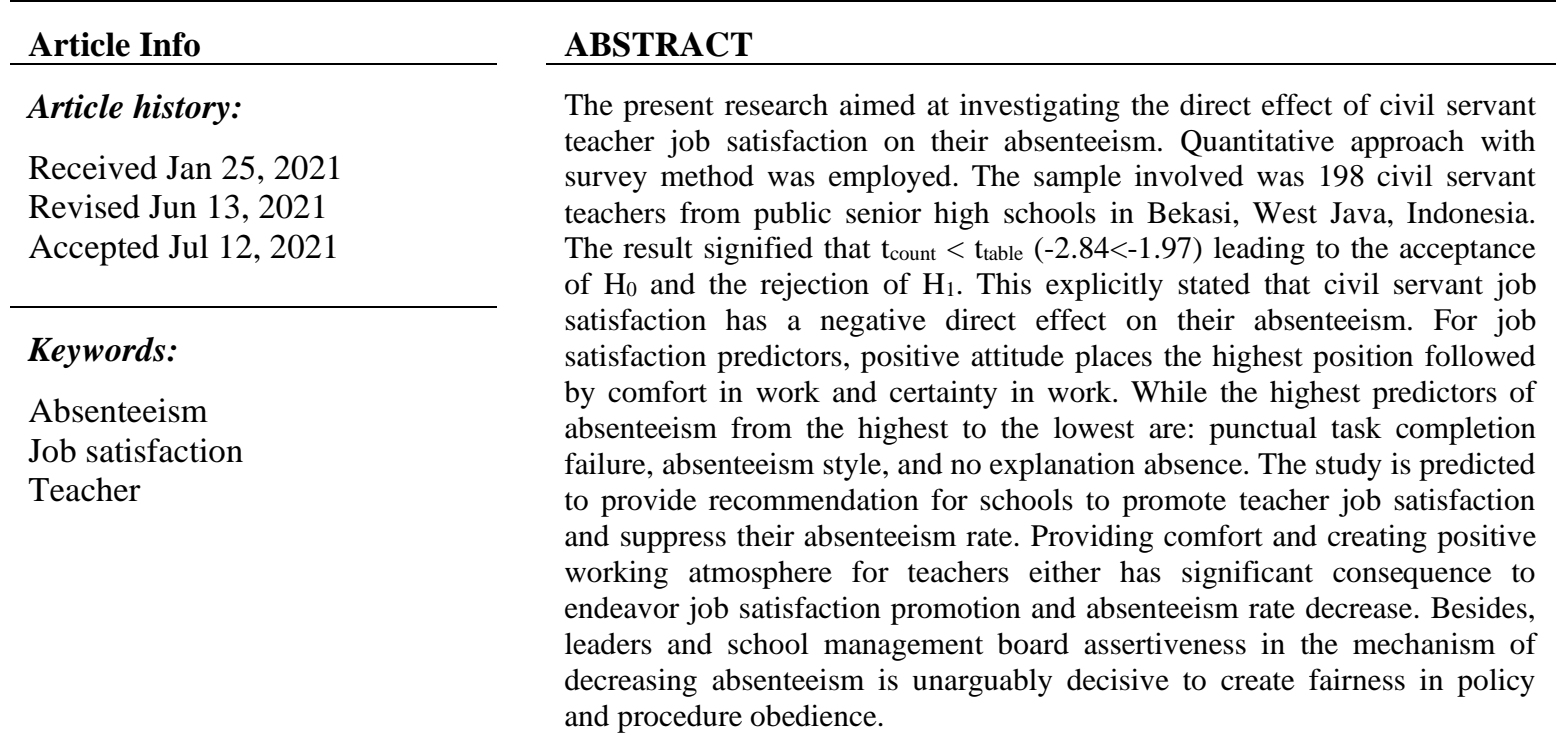

This is an open access article under the CC BY-SA license.

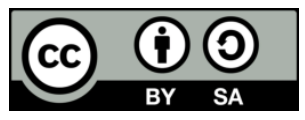

\section{Corresponding Author:}

Purwani Puji Utami

Civics Education Study Program

STKIP Kusuma Negara

Jl. Raya Bogor Km.24 Cijantung, Jakarta Timur, 13770, Indonesia

Email: purwani_puji@stkipkusumanegara.ac.id

\section{INTRODUCTION}

As organizations depend on a lot on their employees, their success is determined by the presence of employees. Employee absenteeism is a severe and unfavorable condition for organizations. According to Badubi [1], the act of absenteeism performed by employees is a catastrophe for organizations. Gupta [2] even calls this absenteeism as an "illness" to damage sustainable existence of organizations. To be more extreme, Swarnalatha and Sureshkrishna [3] call absenteeism as a threat to organizations.

Absenteeism surely gives impact on organizations for a number of crucial things. Research conducted by Onikoyi, et al. [4] and Omari, et al. [5] claimed that absenteeism crucially influences employee performance, and even their morality [6]. To go further, Raja and Gupta [7] mentioned that absenteeism specifically gives quite an impact on organizational productivity with special reference to service sector. Kocakülâh, et al. [8] widened the scope of how absenteeism gives effect to productivity, efficiency and 
profitability. While, Singh, et al. [9] openly affirmed that employee absenteeism inflicts organization service to clients, loss of business, productivity decrease, and cost increase.

Absenteeism does not only happen in organizations like companies or enterprises, but also occurs at schools as educational institutions. Teacher absenteeism is reported to affect student learning [10], achievement [11], and performance [12]. If this condition remains for a very long time, school quality deterioration cannot be avoided. Analytical and Capacity Development Partnership (ACDP) [13] reported that in 2014, teacher absenteeism rate (at primary and junior high school level) in Indonesia is quite high. Based on region, teachers in Kalimantan were reported to have the highest absenteeism (14.1\%), followed by Bali and Nusa Tenggara (14.0\%), Papua and Maluku (11.6\%), Sulawesi (10.2\%), Java (9.1\%) and Sumatera $(8.4 \%)$. The high rate of teacher absenteeism in Indonesia was also reported by Rogers and Vegas [14]. They narrated that teacher at primary level in Indonesia place the 3rd position in absenteeism during 2002-2003 with $19 \%$ of absenteeism from the six countries studied. While in the period of 2008, Indonesia was observed to be in the 9th position as reported by UNCEN [13]. It was noticed that factors such as official teachingrelated duties $(26.4 \%)$, illness $(14.2 \%)$, not arrived yet $(10.3 \%)$ are the top three reasons of the teacher absenteeism [13].

Basically, there are a number of factors causing teacher absenteeism. An assumption arisen that job satisfaction is one of the factors influencing the absence of an employee attendance at work [15]. They list teacher satisfaction has something to do with extrinsic job satisfaction comprising of: 1) Salary; 2) Workload; 3) Work environment; and 4) Opportunities for professional development.

The assertion of job satisfaction impact on absenteeism is proven in some research. The study of Thirulogasundaram and Sahu [16] in a corporate sector has underlined how job satisfaction correlates positively to absenteeism. They claimed extrinsic job satisfaction is the main contributor to absenteeism [17]. A positive direct linkage between employee job satisfaction and absenteeism was detected in a research conducted by Swarnalatha and Sureshkrishna [3] to a number of employees in automotive industries in India. In health sector, a significant effect of nurse job satisfaction on absenteeism was also found out by Jalal et al. [18]. Absence because of sick, reprimand, teamwork, spouse's job, turnover and work-life quality are the factors behind the absenteeism. A number of teachers in Nigeria either showed that their absenteeism is affected by their job satisfaction [19]. Recent studies pointed out moderate correlation between job absenteeism and employee absences [20], [21].

However, although surveys on teacher absenteeism in Indonesia has been conducted by ACDP, particular studies on permanent or civil servant teacher absenteeism have not almost been found in Indonesia. Such studies are regarded momentous to see whether civil servant teachers have performed their duties and functions appropriately. On that ground, the present study attempts to find out how permanent or civil servant teacher job satisfaction affects their absenteeism from schools by applying a number of predictors from the two variables.

Conceptually, the present study was projected to strengthen and enrich the theoretical foundation of job satisfaction and absenteeism particularly in the investigation of what factors or predictors may influence one to another. Practically, it was estimated that the present study findings may serve as consideration for school principals, top leaders or managers at schools to develop and encourage much more heavenly and satisfying work environment to advance school quality.

\section{RESEARCH METHOD}

The present study utilized quantitative approach with survey method. It was utilized to investigate the causal relationship between civil servant teacher job satisfaction and absenteeism. The population involved in this research was civil servant teachers of public senior high schools of Bekasi Municipality, West Java, Indonesia. They were 394 teachers from 12 public senior high schools (1, 2, 3, 6, 8, 9, 12, 13, 14, 15, 17, 18). Applying purposive random sampling, 198 civil servant teachers were selected as the samples. The sample size of the present study applied the Slovin formula as:

$$
n=\frac{N}{1+\mathrm{N} e^{2}}
$$

Description:

$1=$ constants

$\mathrm{n}=$ sample size

$\mathrm{N}=$ number of populations

$\mathrm{e}^{2}=$ critical value/desired accuracy limit 


$$
n=\frac{394}{1+394(0.05)^{2}}=198.4=198
$$

Table 1 describes the demographic data of civil servant teachers as the samples of the present study. Table 1 illustrates that, being viewed from gender; the respondents are dominated by female with 115 teachers $(58.1 \%)$. Categorized from level of education, the respondents mostly come from bachelor degree level with 136 teachers or $68.7 \%$ from the total percentage. Based on age, most respondents (71 teachers or about $35.9 \%$ ) are $47-58$ years old. While based on the category of working period or years of working, the respondents mostly have been working for 13-24 years (39.4\%).

Table 1. Demographic data of respondents

\begin{tabular}{llcc}
\hline & Criteria & Count & Percentage \\
\hline Gender & Male & 83 & 41.9 \\
\multirow{3}{*}{ Education } & Female & 115 & 58.1 \\
& Bachelor & 136 & 68.7 \\
& Master & 53 & 26.8 \\
Age & Doctor & 9 & 4.5 \\
& 23-34 years old & 59 & 29.8 \\
\multirow{4}{*}{ Working period } & 35-46 years old & 68 & 34.3 \\
& 47-58 years old & 71 & 35.9 \\
& 1-12 years & 72 & 36.4 \\
& 13-24 years & 78 & 39.4 \\
& 25-36 years & 48 & 24.2 \\
\hline
\end{tabular}

The present study objective is to find out the empirical evidence of correlation between civil-servant job satisfaction and their absenteeism. The research question is stated as: Is there any positive direct influence of civil servant teacher job satisfaction on their absenteeism? Accordingly, the following hypotheses are proposed.

$\mathrm{H}_{0}$ : Civil servant job satisfaction gives no positive direct influence on absenteeism

$\mathrm{H}_{1}$ : Civil servant job satisfaction gives positive direct influence on absenteeism

The endogenous variable of the present study is absenteeism (Y) and the exogenous variable is job satisfaction (X). The research design is illustrated in Figure 1.

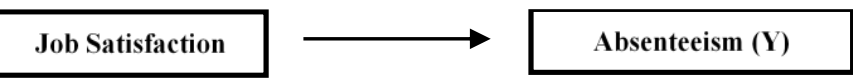

Figure 1. Constellation model of research problems

Questionnaire was used to collect the data. The questionnaire given to the samples consisted of two. The first questionnaire used job satisfaction variable with the following indicators: 1) Comfort in work; 2) Certainty in work; and 3) Positive attitude. The second one utilized absenteeism variable with these indicators: 1) Punctual task completion failure; 2) No explanation absence; and 3) Absenteeism style when getting frequent punishment.

The procedure of collecting the data consists of three main steps. First, piloting test on the questionnaire was first performed to check the validity and reliability of the instruments. In this phase, 30 respondents were involved. The second phase was analyzing the data obtained from piloting test to determine valid and reliable items of the questionnaire. Having checked the questionnaire, the last step to do was distributing it to 198 civil servant teachers. Having collected the data, a number of statistical tests were applied to provide comprehensive data presentation, consisting of: 1) Analyzing data using descriptive statistical computation; 2) Testing normality of data; 3) Checking linearity regression; and 4) Applying path coefficient structure test and testing hypothesis.

\section{RESULTS AND DISCUSSION}

\subsection{Negative direct influence of teacher job satisfaction on absenteeism}

The data collected from the questionnaire were first analyzed using descriptive statistics. The result is presented in Table 2. The numbers displayed are to provide general information of job satisfaction (X 
variable) and absenteeism (Y variable). Several aspects are calculated: mean, standard error, media, mode, standard deviation, sample variance, range, minimum-maximum numbers of two variables completed by sum and count. It can be viewed that the job satisfaction data has theoretical score range from 34 to 170, and the empirical score range is between 106-156, so that the range calculated is 50 . The mean of data calculation is 130.95 ; the standard deviation is 11.94 ; the variance is 142.53 ; the median is 132.50 ; and the mode is 128.00 . Then, the data of absenteeism display show 34 to 170 for theoretical score range, and empirical score range is between 116-169. Thus, the gained score is 53. The mean obtained is 142.66; the standard deviation is 12.58; the variance is 158.23; the median is 143.00; and the mode is 154.00.

The next calculation to apply was normality checking. Lilliefors statistical computation reveals the normality score of $\mathrm{X}$ on $\mathrm{Y}$ is 0.0462 . The critical value for $\mathrm{n}=198$ at significant level $\alpha=0.05$ is 0.0630 . The

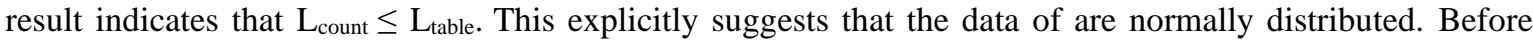
further analysis to draw conclusion, significance and linearity test was conducted in advance. The result is presented in Table 3.

Table 2. Research data description

\begin{tabular}{cccc}
\hline No. & Statistical description & Job satisfaction $(\mathrm{X})$ & Absenteeism $(\mathrm{Y})$ \\
\hline 1. & Mean & 130.95 & 142.66 \\
2. & Standard error & 0.848 & 0.894 \\
3. & Median & 132.50 & 143.00 \\
4. & Mode & 128.00 & 154.00 \\
5. & Standard deviation & 11.94 & 12.58 \\
6. & Sample variance & 142.53 & 158.23 \\
7. & Range & 50 & 53 \\
8. & Minimum & 106 & 116 \\
9. & Maximum & 156 & 169 \\
10. & Sum & 25929 & 28246 \\
11. & Count & 198 & 198 \\
\hline
\end{tabular}

Table 3. ANAVA (Significance test and regression linearity test)

\begin{tabular}{|c|c|c|c|c|c|c|}
\hline \multirow{2}{*}{ Variance } & \multirow{2}{*}{ df } & \multirow{2}{*}{$\begin{array}{c}\text { Sum of squared } \\
\text { error }\end{array}$} & \multirow{2}{*}{$\begin{array}{c}\text { Root mean } \\
\text { square }\end{array}$} & \multirow[b]{2}{*}{$F_{\text {count }}$} & \multicolumn{2}{|c|}{$\mathrm{F}_{\text {table }}$} \\
\hline & & & & & $\alpha=0.05$ & $\alpha=0.01 * *$ \\
\hline Total & 198 & 4060648 & & & & \\
\hline Regression a & 1 & 4029477.35 & & & & \\
\hline Regression $\mathrm{b} / \mathrm{a}$ & 1 & 3625.89 & 3625.89 & $25.80 * *$ & 3.89 & 6.77 \\
\hline Residual & 196 & 27544.75 & 140.53 & & & \\
\hline Standard error of & 40 & 4883.43 & 122.09 & $0.840^{\mathrm{ns}}$ & 1.47 & 1.72 \\
\hline the estimate & 156 & 22661.32 & 145.26 & & & \\
\hline
\end{tabular}

The significance test of regression of $\mathrm{X}=189.715-0.359 \mathrm{Y}$ points out $\mathrm{F}_{\text {count }} 25.80>\mathrm{F}_{\text {table }}(0.01 ; 1: 196) 6.77$ at significance level $\alpha=0.01$. Wherefore, the regression is stated very significant. For the linearity test, it is found that $F_{\text {count }} 0.840<F_{\text {table }(0.05: 40: 156)} 1.47$ at significance level $\alpha=0.05$. For that reason, the estimated point of linear line is acceptable. The point distribution which is nearly located to linearity line is visible in Figure 2.

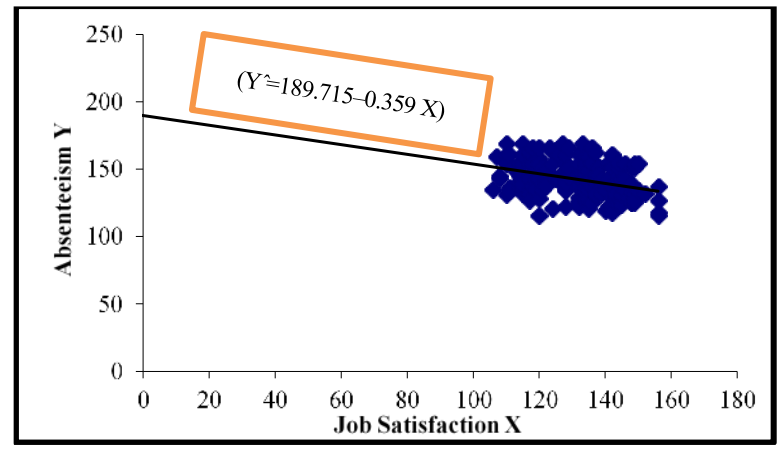

Figure 2. Linear regression graphic $\left(\mathrm{Y}^{\wedge}=189.715-0.359 \mathrm{X}\right)$ 
Path coefficient structure test was applied with the intention to check the direct effect of job satisfaction on teacher absenteeism. The result is presented in Table 4. Table 4 describes that path coefficient gained is -0.207 with df 195 . While $t_{\text {count }}$ value is -2.84 and $t_{\text {table }}$ is -1.97 at level of significance 0.05 , and -2.60 at level of significance 0.01 . It is obviously seen that the $t_{\text {table }}$ is much higher than $t_{\text {count }}$. This clearly denotes that $\mathrm{H}_{0}$ is accepted while $\mathrm{H}_{1}$ is rejected.

Table 4. Summary result of path significance test

\begin{tabular}{lccccc}
\hline \multirow{2}{*}{ Direct influence } & Path coefficient & df & $\mathrm{t}_{\text {count }}$ & \multicolumn{3}{c}{$\alpha=0.05^{*} \mathrm{t}_{\text {table }}$} \\
& & & & $\alpha=0.01 * *$ \\
\hline $\mathrm{X}$ on $\mathrm{Y}$ & -0.207 & 195 & -2.84 & -1.97 & -2.60 \\
\hline *Significant $\left(\mathrm{t}_{\text {count }}<\mathrm{t}_{\text {table }}\right.$ at $\left.\alpha=0.05\right)$ : negative effect \\
**Very significant $\left(\mathrm{t}_{\text {count }}<\mathrm{t}_{\text {table }}\right.$ at $\left.\alpha=0.01\right)$ : negative effect
\end{tabular}

The acceptance precisely states that job satisfaction gives no positive direct influence on absenteeism. It further implies that if the teachers are satisfied with their job, their tendency to perform absenteeism will decrease. This phenomenon shall occur as the civil servant teachers may have got what they deserve during working on their functions and duties both as civil servants and educators. This corresponds to the low level of their absenteeism.

The result of the present study is in conformity with a study conducted by Wambua [22]. She found out that public primary school teacher job satisfaction gives insignificant impact on their absenteeism. Gender, length of a teacher's service time in school, income, age, and teaching experience also was claimed not to affect absenteeism. Furthermore, it was also detected that employee job satisfaction is significantly connected with absenteeism although it is influenced by some factors including type of work, workers' attitude, behavior and goals [23], [24].

Congruent with the above studies, Drakopoulos and Grimani [25], [26] who previously conducted a similar research to market laborers, reported that there is a weak negative relationship of job satisfaction and absenteeism. They predicated the two variables might have a stronger relation under particular condition. Pursuant to the present and previous research findings, the research of Rao [27] and Schalk and van Rijckevorsel [28] in service sector either did not find any obvious evidence of job satisfaction and absenteeism correlation.

The finding of this study also exhibits similar discovery as reported by the following research. Hausknecht, et al. [29] found out that the negative relation between job satisfaction and absenteeism is not detected in shared satisfaction. However, absenteeism is identified in unit level satisfaction and commitment. Josias [30] in his research has noted a weak inverse relationship between job satisfaction and absenteeism. Job level used as the predictor is not mentioned to give significant effect on the numbers of employees' day off. Having found out no correlation between job satisfaction and absenteeism, Mashonganyika [31] even stressed that the theory of low job satisfaction directing to high absenteeism is not supportable.

Notwithstanding, the present study result shows contrary with the findings of Ejere [19], Jalal, et al. [18], Obasan [17], Swarnalatha and Sureshkrishna [3], and Thirulogasundaram and Sahu [16]. Although no revelation of positive relation, studies conducted by Schaumberg and Flynn [20], and Jaarsveld and Keyser [21] unveiled moderate correlation between the two variables. The contradiction assuredly represents that the connection of these two variables is always under particular condition; factor, facet, indicator or predictor used to measure the connection will determine the result of studies. Following the opinion of Wee, et al. [32] that combination of socioeconomic, physical and mental health factors will result in different expectation of variables researched. To conclude, Lu, et al. [33] assuredly avowed that studies conducted to see the connection between job satisfaction and absenteeism yields disputable results, between positive and negative.

\subsection{Predictors affecting job satisfaction and absenteeism}

The present study does not find any positive correlation between civil servant job satisfaction and their absenteeism. Nonetheless, the analysis of the indicators used to estimate the relation is suggestive.

\subsubsection{Predictors of job satisfaction}

The predictors used to measure civil servant job satisfaction cover these three following things: comfort in work, certainty in work, and positive attitude. The item score calculation result of job satisfaction is presented in Table 5. The whole percentage of job satisfaction indicators is visualized in Figure 3. 
Table 5. Item score of job satisfaction variable (X)

\begin{tabular}{ccccc}
\hline No & Indicator & Total item & Average answer per indicator & Percentage \\
\hline 1 & Comfort in work & 11 & 3.88 & 33.63 \\
2 & Certainty in work & 9 & 3.75 & 32.53 \\
3 & Positive attitude & 14 & 3.90 & 33.84 \\
& Total & 34 & 11.52 & 100 \\
\hline
\end{tabular}

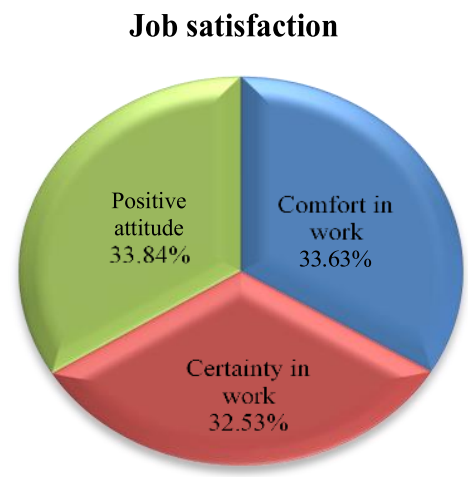

Figure 3. Job satisfaction indicator percentage

Positive attitude is observed to be the highest predictor of civil servant teacher job satisfaction with percentage $33.84 \%$. Such attitude is categorized into intrinsic satisfaction in reference to theory of Herzberg [34] as this attitude is derived from the employees' perception of their work itself. The finding is in accordance with a study reported by Arokiasamy [35] contending that internal factor influences employee job satisfaction. Employee recognition, promotion possibility, and fairness are claimed to give significant impact on job satisfaction. Raza et al.'s research [36] revealed intrinsic factor significant and positive effect on job satisfaction. They used job security, achievement, job responsibility and work itself as the measurement. Using different intrinsic facets to measure job satisfaction, Suhartono [37] explicitly recognized that intrinsic factors do affect job satisfaction. He listed commitment and work professionalism as the two determining factors.

The second and third predictors used to measure the civil servant teacher job satisfaction are comfort in work $(33.63 \%)$ and certainty in work $(32.53 \%)$. The predictors theoretically can be grouped to extrinsic satisfaction as they may have something to do with workplace physical condition, payment or salary, relationship with co-workers, working duration, supervision from company management, rules and policies in work, job security, status and personal life. The finding of predictors is in compliance with the lists of previous research. Abuhashesh, et al. [38] have proven that extrinsic facets impact on job satisfaction. Position and salary are particularly reported as the most forceful facets. Previous research conducted by Arif [39] depicted different result; non-monetary predictors are uttered as influencers in job satisfaction. Bonuses and pay are also exerting indicators in job satisfaction [40]. Besides money or pay, supervisory relationship is proven to play critical role in employee job satisfaction [41]. Work environment either highly contributes to job satisfaction [42], [43]. Constituting into more detail result, workload apparently gives eloquent impact on job satisfaction [44]. To accelerate employee job satisfaction, Abubaha [45] suggestively announced to organization to concern on supportive leadership and rewards, either financial or non-financial ones.

\subsubsection{Predictors of absenteeism}

The predictors of absenteeism observed from the 198 civil servant teachers are punctual task completion failure, absenteeism style when getting frequent punishment, and no explanation absence. Table 6 displays the data of absenteeism item score. Figure 4 exhibits the whole percentage of the item score.

Table 6. Item score of absenteeism variable (Y)

\begin{tabular}{ccccc}
\hline No & Indicator & Total item & Average answer per indicator & Percentage \\
\hline 1 & Punctual task completion failure & 15 & 4.35 & 34.14 \\
2 & No explanation absence & 14 & 4.10 & 32.17 \\
3 & Absenteeism style when getting frequent punishment & 5 & 4.29 & 33.69 \\
& Total & 34 & 12.73 & 100 \\
\hline
\end{tabular}




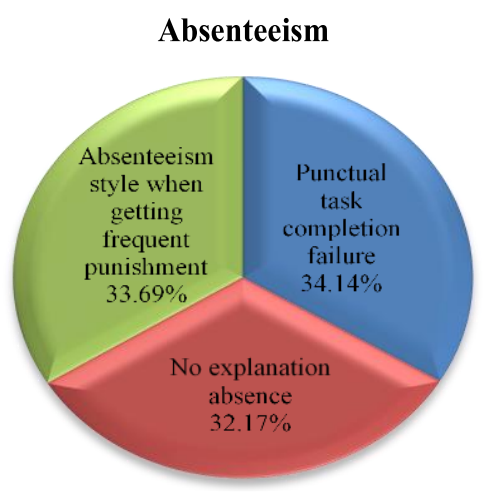

Figure 4. Absenteeism indicator percentage

The highest predictor found in the present study is task completion failure (34.14\%). This is a part of job situation factor as notified by Amstrong [46]. Corresponding to the present study result, job situation is a prevailing factor in employee absenteeism [8], [47]. Particularly, immoderate workload as a part of job situation tends to increase employee avoidance from work [48]. Pursuant to job situation, Smokrović, et al. [49] attributed physical working condition as pivotal factor in absenteeism. Another predictor of job situation factor which becomes the trend in absenteeism is stress [50]-[53]. Stress can be dealing with workload, poor working conditions, shift work, role ambiguity or conflict, relationships and organizational climate.

The second predictor is absenteeism style when getting frequent punishment (33.69\%). This predictor is grouped as a personal factor as cited by Amstrong [46]. In consonant with the result of the present study, Obiero, et al. [54] ascertained that personal factor or private life matters is a key factor on absenteeism although they used different predictors in conducting their research. Health problem specifically illness is also confirmed as a personal factor to prevent employees from attending their job [55], [56].

The third predictor used to determine absenteeism is no explanation absence $(32.17 \%)$. This is also included in personal factor as in agreement with Amstrong [46], specifying that an employee may be an absence-prone. Čikeš, et al. [57] stressed that the most frequent cause of employee absenteeism is employee attitudes at work, in which attitudes are a part of personality realization [58] as cited in Purwani, et al. [59]. Further, this is plainly evident of excused absence as underlined by Jex [60]. Such predictor had also been researched by Dubey and Dasgupta [61]. They found out that such absenteeism is due to lack of leisure time, personal need fulfilment and interest decrease in job. Possibility of reducing absenteeism rate in organizations is extremely low. For that reason, strategies to improve presence should be taken into consideration. Employee engagement, promotion, communication and work-life balance are highly suggested to perform [62]. Likewise, rules and policies as well as positive working atmosphere are vitally important in decreasing absence rate [63]. Leadership support and companionship, together with reasonable compensation are either supportable to avoid absence from work [64].

\section{CONCLUSION}

The present study's intention is to investigate the direct impact of job satisfaction on civil servant absenteeism. As a final point, the findings and discussion of the present study signify that job satisfaction has negative direct impact on their absenteeism. This further implies that the civil servant teacher needs and necessities have been already complied so that they have no more excuses for not attending work. The first finding is in consonance with a number of researches unveiling the negative correlation between the two variables. Howbeit, at the same time, the result disconfirms the other previous research result disclosing positive significant relation between job satisfaction and absenteeism.

However, although the correlation shows no significant effect, the analysis of job satisfaction and absenteeism predictors as the second finding is worth to notice. In job satisfaction, the highest predictor is positive attitude categorized into intrinsic satisfaction. The second and third predicator is comfort in work and certainty in work which are classified into extrinsic satisfaction. In absenteeism, the first top predictor is punctual task completion failure grouped to job situation factor, followed by absenteeism style when getting frequent punishment, and the last is no explanation absence; both are parts of personal factors. The conclusion directs us to a notion that different various factors or predictors shall determine the result of studies whether it is positive or negative. Comprehensive studies on how extrinsic and intrinsic job satisfaction thoroughly affects absenteeism on job, personal and attendance factor are highly recommended. 


\section{REFERENCES}

[1] R. M. Badubi, "A critical risk analysis of absenteeism in the work place," J. Int. Bus. Res. Mark., vol. 2, no. 6, pp. 32-36, 2017, doi: 10.18775/jibrm.1849-8558.2015.26.3004.

[2] B. Gupta, "Employees absenteeism : Barrier for retail sector organization success," Int. J. Eng. Manag. Res., vol. 3, no. 6, pp. 88-92, 2013. [Online]. Available: http://www.ijemr.net.

[3] C. Swarnalatha and G. Sureshkrishna, "Absenteeism - A menace to organization in building job satisfaction among employees in automotive industries in India," Tactful Manag. Res. J., vol. 1, no. 4, pp. 1-6, 2013.

[4] A. I. Onikoyi, O. D. Awolusi, and B. M. Ayodeji, "Effect of Absenteeism on Corporate Performance: a Case Study of Cadbury Nigeria Plc, Ikeja, Lagos State, Nigeria," Br. J. Mark. Stud., vol. 3, no. 2, pp. 58-71, 2015. [Online]. Available: www.eajourmals.org.

[5] G. Omari, S. Manyele, and G. Mwaluko, "Analysis of measured employees' absenteeism in the forensic science laboratory," Engineering, vol. 11, no. 3, pp. 137-166, 2019, doi: 10.4236/eng.2019.113012.

[6] K. E. Joseph, "Gauging the issue of absenteeism in the workplace : Evidence from the public," Int. J. Bus. Soc. Sci., vol. 6, no. 2, pp. 65-71, 2015.

[7] H. Raja and R. Gupta, "The impact of employee absenteeism on organizational productivity with special reference to service sector," IMPACT Int. J. Res. Humanit. Arts Lit. (IMPACT IJRHAL), vol. 7, no. 4, pp. 581-594, 2019. [Online]. Available: https://www.impactjournals.us.

[8] M. C. Kocakülâh, T. G. Bryan, and S. Lynch, "Effects of absenteeism on company productivity, efficiency, and profitability," Bus. Econ. Res., vol. 8, no. 1, pp. 115-135, 2018, doi: 10.5296/ber.v8i1.12395.

[9] T. Singh, N. Chetty, and A. M. Karodia, "An investigation into the impact of absenteeism on the organisational performance of a private security company in Durban, Kwazulu-Natal," Singaporean J. Bus. Econ. Manag. Stud., vol. 4, no. 11, pp. 105-159, 2016.

[10] D. Buck, "What's Behind the Epidemic of Chronic Teacher Absenteeism?" Foundation for Economic Education, 2019. [Online]. Available: https://fee.org/articles/whats-behind-the-epidemic-of-chronic-teacher-absenteeism. (accessed Jul. 08, 2020).

[11] R. T. Miller, R. J. Murnane, and J. B. Willett, "Do teacher absences impact student achievement? Longitudinal evidence from one urban school district," National Bureau of Economic Research, 2007. [Online]. Available: http://www.nber.org/papers/w13356.

[12] J. Muasya, "Effects of teacher absenteeism on pupils' kcpe performance in public and private primary schools in Kitui central sub-county, Kenya," Master Thesis, University of Nairobi, Kenya, 2016. [Online]. Available: http://erepository.uonbi.ac.ke/handle/11295/97314.

[13] Analytical and Capacity Development Partnership (ACDP), "Study on Teacher Absenteeism in Indonesia 2014 Analytical and Capacity Development Partnership (ACDP)," 2014. [Online]. Available: www.acdp-indonesia.org.

[14] F. Rogers and E. Vegas, "No more cutting class? Reducing teacher absence and providing incentives for performance," Policy Research Working Papers, 2009. [Online]. Available: https://doi.org/10.1596/1813-94504847.

[15] G. Guerrero, J. Leon, M. Zapata, C. Sugimaru, and S. Cueto, "What works to improve teacher attendance in developing countries? A systematic review," EPPI-Centre, Social Science Research Unit, Institute of Education, University of London, London, 2012.

[16] V. P. Thirulogasundaram and P. C. Sahu, "Job satisfaction and absenteeism interface in corporate sector - A study," IOSR J. Humanit. Soc. Sci., vol. 19, no. 3, pp. 64-68, 2014, [Online]. Available: http://www.iosrjournals.org.

[17] K. Obasan, "Impact of job satisfaction on absenteeism: A correlative study," Eur. J. Humanit. Soc. Sci., vol. 1, no. 1, pp. 25-49, 2011. [Online]. Available: http://www.journalsbank.com/ejhss.htm.

[18] E. Jalal, F. Hajibabaee, M. Farahaninia, S. Joolaee, and F. Hosseini, "Relationship between job satisfaction, absence from work and turnover among nurses," J. Nurs. Midwifery Sci., vol. 1, no. 1, pp. 12-18, 2014, doi: $10.4103 / 2345-5756.231385$.

[19] E. I. Ejere, "Absence from work: A study of teacher absenteeism in selected public primary schools in Uyo, Nigeria," Int. J. Bus. Manag., vol. 5, no. 9, pp. 115-123, 2010, doi: 10.5539/ijbm.v5n9p115.

[20] R. L. Schaumberg and F. J. Flynn, "Clarifying the link between job satisfaction and absenteeism: The role of guilt proneness," J. Appl. Psychol., vol. 102, no. 6, pp. 982-992, 2017, doi: 10.1037/apl0000208.

[21] D. van Jaarsveld and E. Keyser, "The moderating role of job satisfaction on workplace absenteeism and substance use amongst the employees at a power utility in Mpumalanga," J. Econ. Behav. Stud., vol. 10, no. 2(J), pp. 219-230, 2018, doi: 10.22610/jebs.v10i2(J).2231.

[22] G. S. Wambua, "Factors influencing teachers' absenteeism in public primary schools in Ruiru Constituency, Kiambu County," Master Thesis, United States International University - Africa, Nairobi, Kenya, 2015.

[23] S. A. Effendi and M. Z. Romas, "The relationship between job satisfaction and employee's absenteeism at mining division of PT X," (in Bahasa), J. Psikol., vol. 10, no. 1, pp. 38-45, 2014. [Online]. Available: https://ejournal.up45.ac.id/index.php/psikologi/article/view/116.

[24] M. I. B. Ribeiro, G. J. A. Fernandes, and I. M. Lopes, "Absenteeism and job satisfaction in a Portuguese municipality,” J. Organ. Manag. Stud., vol. 2019, no. 2019, pp. 1-11, 2019, doi: 10.5171/2019.168494.

[25] S. A. Drakopoulos and K. Grimani, "Injury-related absenteeism and job satisfaction: Insights from Greek and UK data," Int. J. Hum. Resour. Manag., vol. 24, no. 18, pp. 3496-3511, 2013, doi: 10.1080/09585192.2013.777678.

[26] S. Drakopoulos and A. Grimani, "The relationship between absence from work and job satisfaction: Greece and UK comparisons," Int. J. Hum. Resour. Manag., vol. 24, no. 18, pp. 3496-3511, 2013, doi: 10.1080/09585192.2013.777678. 
[27] S. Rao, "Addressing high rates of public service absenteeism," GSDRC Publications, 2013. [Online]. Available: http://www.gsdrc.org.

[28] R. Schalk and A. van Rijckevorsel, "Factors influencing absenteeism and intention to leave in a call centre," New Technol. Work Employ., vol. 22, no. 3, pp. 260-274, 2007, doi: 10.1111/j.1468-005X.2007.00198.x.

[29] J. P. Hausknecht, N. J. Hiller, and R. J. Vance, "Work-unit absenteeism: Effects of satisfaction, commitment, labor market conditions, and time," Acad. Manag. J., vol. 51, no. 6, pp. 1223-1245, 2008, doi: 10.5465/AMJ.2008.35733022.

[30] B. A. Josias, "The relationship between job satisfaction and absenteeism in a selected field services section within an electricity utility in the Western Cape," Master Thesis, University of The Western Cape, South Africa, 2005. [Online]. Available: http://etd.uwc.ac.za/xmlui/handle/11394/1476.

[31] O. Mashonganyika, "The relationship between job satisfaction and absenteeism: A study of the shop floor workers in a motor manufacturing plant," Master Thesis, Rhodes University, South Africa, 2004.

[32] L. H. Wee, et al., "Anteceding factors predicting absenteeism and presenteeism in urban area in Malaysia," BMC Public Health, vol. 19, no. Suppl 4: 540, pp. 1-12, 2019, doi: 10.1186/s12889-019-6860-8.

[33] H. Lu, Y. Zhao, and A. While, "Job satisfaction among hospital nurses: A literature review," Int. J. Nurs. Stud., vol. 94, no. 2019, pp. 21-31, 2019, doi: 10.1016/j.ijnurstu.2019.01.011.

[34] F. Herzberg, Work and the nature of man. World Publishing, 1966.

[35] A. R. A. Arokiasamy, "Exploring the internal factors affecting job satisfaction in the fast food industry in Malaysia," Int. J. Adv. Appl. Sci., vol. 6, no. 11, pp. 11-20, 2019, doi: 10.21833/ijaas.2019.11.003.

[36] M. Y. Raza, M. W. Akhtar, M. Husnain, and M. S. Akhtar, "The impact of intrinsic motivation on employee's job satisfaction," Manag. Organ. Stud., vol. 2, no. 3, pp. 80-88, 2015, doi: 10.5430/mos.v2n3p80.

[37] Suhartono, "The influence of intrinsic and extrinsic factors on the job satisfaction of the internal auditors of The State Islamic Universities in Indonesia," in 15th International Symposium on Management (INSYMA 2018), 2018, vol. 186, pp. 132-135, doi: 10.2991/insyma-18.2018.33.

[38] M. Abuhashesh, R. Al-Dmour, and R. Masa'deh, "Factors that affect employees job satisfaction and performance to increase customers' satisfactions," J. Hum. Resour. Manag. Res., vol. 2019, no. 2019, pp. 1-23, 2019, doi: $10.5171 / 2019.354277$.

[39] A. A. Arif, "Factors those influence the job satisfaction of school teachers who work for different schools situated in Sylhet city, Bangladesh," IOSR J. Res. Method Educ., vol. 7, no. 1, pp. 26-32, 2017, doi: 10.9790/73880701012632.

[40] O. C. Hee, L. H. Yan, A. M. Rizal, K. O. Tan, and G. C. Fei, "Factors influencing employee job satisfaction: A conceptual analysis," Int. J. Acad. Res. Bus. Soc. Sci., vol. 8, no. 6, pp. 331-340, 2018, doi: 10.6007/ijarbss/v8i6/4207.

[41] L. Rani, L. Y. Mee, M. Lee, and L. T. Heang, "Intrinsic and extrinsic factors in relation to junior auditors' job satisfaction and turnover intention," Int. Acad. Res. J. Bus. Technol., vol. 4, no. 1, pp. 8-20, 2018.

[42] W. Sittisom, "Factors affecting job satisfaction of employees in pharmaceutical industry: A case study of Thailand," Syst. Rev. Pharm., vol. 11, no. 3, pp. 125-133, 2020, doi: 10.5530/srp.2020.3.14.

[43] T. S. Suifan, "The effects of work environmental factors on job satisfaction: The mediating role of work motivation," Bus. Theory Pract., vol. 20, pp. 456-466, 2019, doi: 10.3846/btp.2019.42.

[44] T. Srimarut and W. Mekhum, "The influence of workload and co-worker attitude on job satisfaction among employees of pharmaceutical industry in Bangkok, Thailand: The mediating role of training," Syst. Rev. Pharm., vol. 11, no. 2, pp. 603-611, 2020, doi: 10.5530/srp.2020.2.88.

[45] A. Abubaha, "Job satisfaction strategies to improve performance of small businesses," Ph.D Dissertation, Walden University, Minnesota, USA, 2019.

[46] M. Amstrong, Armstrong's handbook of human resource management practice. London: Kogan Page, 2009.

[47] S. Aishwariyashindhe, J. Sathyapriya, P. S. Vijayalakshmi, and Sudha, "Factors influencing employee absenteeism in IT companies at Trichy," Int. J. Recent Technol. Eng., vol. 8, no. 2 Special Issue 6, pp. 856-859, 2019, doi: 10.35940/ijrte.B1159.0782S619.

[48] K. R. Augustino, "An assessment on the impact of employees absenteeism on performance in local government authorities: A case of Busokelo district council," Ph.D Dissertation, The Open University of Tanzania, Tanzania, 2017. [Online]. Available: http://repository.out.ac.tz/1744.

[49] E. Smokrović, M. F. Žvanut, A. Bajan, R. Radić, and B. Žvanut, "The effect of job satisfaction, absenteeism, and personal motivation on job quitting: A survey of Croatian nurses," J. East Eur. Manag. Stud., vol. 24, no. 3, pp. 398-422, 2019, doi: 10.5771/0949-6181-2019-3-398.

[50] M. U. Kottwitz, V. Schade, C. Burger, L. Radlinger, and A. Elfering, "Time pressure, time autonomy, and sickness absenteeism in hospital employees: A longitudinal study on organizational absenteeism records," Saf. Health Work, vol. 9, no. 1, pp. 109-114, 2018, doi: 10.1016/j.shaw.2017.06.013.

[51] R. J. Butler and W. G. Johnson, "The determinants of nursing turnover: A multi-year analysis," Med. Res. Arch., vol. 8, no. 6, pp. 1-15, 2020, doi: 10.18103/mra.v8i6.2144.

[52] S. Syahlan, F. Zulkefli, M. Z. Muhammad, and S. Sani, "Factors affecting employee absenteeism in oil palm estate," Int. J. Acad. Res. Bus. Soc. Sci., vol. 10, no. 4, pp. 110-118, 2020, doi: 10.6007/IJARBSS/v10-i4/7112.

[53] P. H. Bórsdóttir, "Absenteeism and the effectiveness of absence management and health policies: The case of an Icelandic hotel chain,” Master Thesis, Reykjavik University, Iceland, 2018. 
[54] E. O. Obiero, B. R. Mwebi, and N. M. Nyang'ara, "Factors influencing teacher absenteeism in public secondary schools in Borabu Sub-County, Kenya," Int. J. Educ. Res., vol. 5, no. 7, pp. 123-138, 2017. [Online]. Available: www.ijern.com.

[55] N. M. Alreshidi, R. M. Alaseeri, and M. Garcia, "Factors influencing absenteeism among nursing staff in the primary health care centers in Hail : A pleriminary study for enhancing staff commitment," Heal. Sci. J., vol. 13, no. 3, pp. 1-7, 2019, doi: 10.21767/1791-809X.1000658.

[56] S. Poongvanam, "Employee absenteeism - A case study of leather firm in Vellore," Int. J. Res. Soc. Sci., vol. 7, no. 10, pp. 7-21, 2017.

[57] V. Čikeš, H. M. Ribarić, and K. Črnjar, "The determinants and outcomes of absence behavior: A systematic literature review," Soc. Sci., vol. 7, no. 8, 2018, doi: 10.3390/socsci7080120.

[58] S. P. Robbins and T. Judge, Organizational behavior. New Jersey: Pearson Education Inc., 2017.

[59] P. P. Utami, A. D. Widiatna, S. Ayuningrum, A. Putri, H. Herlyna, and A. Adisel, "Personality: How does it impact teachers' organizational commitment?" Cakrawala Pendidik., vol. 40, no. 1, pp. 120-132, 2021, doi: 10.21831/cp.v40i1.33766.

[60] S. M. Jex, Organizational psychology: A scientist practitioner approach. New York: John Wiley \& Sons, 2002.

[61] K. Dubey and P. Dasgupta, "A study on absenteeism and its co-relation with job satisfaction with special reference to IT sector," Glob. J. Commer. Manag. Perspect., vol. 4, no. 3, pp. 23-38, 2015.

[62] A. N. S. Forte, "Strategies for reducing employee absenteeism for a sustainable future: A Bermuda perspective," Ph.D Dissertation, Walden University, USA, 2017.

[63] D. R. Johnson-Tate, "Effective strategies used by restaurant managers to reduce employee absenteeism," Ph.D Dissertation, Walden University, USA, 2018.

[64] P. M. Manning, "Strategies for reducing employee absenteeism in retail stores," Ph.D Dissertation, Walden University, USA, 2017. 